\title{
THE AVAILABILITY OF THE WORK PRODUCT OF A DISQUALIFIED ATTORNEY: WHAT STANDARD?
}

To fulfill his professional responsibilities, an attorney must be guided by his obligations both to clients and the legal profession. ${ }^{1}$ When he represents a client in litigation in which the adverse party is either a current ${ }^{2}$ or a former ${ }^{3}$ client, the attorney may be unable to discharge his obligations. ${ }^{4} \mathrm{He}$ may be unable to preserve the confidences and secrets of his clients ${ }^{6}$ or exercise independent pro-

1 These obligations are set forth in the ABA Code of Professronal ResponSIBIITy [hereinafter cited as CODE]. The Code succeeded, in 1970, the ABA Canons of Professional Etaics [hereinafter cited as Canons], which were adopted in 1908. Preface to CoDE at i, ii (1976).

The Code has been substantially adopted by the District of Columbia and all states except California. R. Wise, Legal Etrircs ix (Supp. 1977); Note, Attorney's Conflict of Interest: Representation of Interest Adverse to That of Former Client, 55 B.U. L. Rev. 61, 65 n.23 (1975) [hereinafter cited as B.U. L. Rev. Note]. In the federal courts, the Code has been incorporated into local rules, e.g., D. NEB. R. 5B; N.D. OKLA. R. 5(j); E.D. PA. R. 11, or is used as a standard for ethical conduct. E.g., Fund of Funds, Ltd. v. Arthur Andersen \& Co., 567 F.2d 225, 227 n.2 (2d Cir. 1977); Woods v. Covington County Bank, 537 F.2d 804, 810 (5th Cir. 1976). See generally Comment, Conflicts of Interest and the Former Government Attorney, 65 Geo. L.J. 1025, 1033 n.36 (1977).

The Code has recently been subject to increasing criticism, e.g., G. HAZARD, Ethics in the Practice of Law (1978); J. Lieberisan, Crists at the Bar (1978), and currently is under revision. Both criticism of the Code and speculation on possible future revision are outside the scope of this Comment.

2 This situation is referred to as "simultaneous representation." This term encompasses litigation in which an attorney represents adverse parties. Such an occurrence is rare, however, and will not be considered in this Comment.

3 This situation is referred to as "successive representation."

4 The discussion in this Comment is limited to conflicts generated exclusively in private legal practice. The peculiar problems of a former government attorney in private practice are confronted in DR 9-101(B). See generally G. HAzARD, supia note 1, at 107-19; J. LnEBERMAN, supra note 1, at 176-80; Jordan, Ethical Issues Arising from Present or Past Government Service, in Profressional ResponSIBIITY 171-217 (D. Ream. ed. 1978); Kaufman, The Former Government Attorney and the Canons of Professional Ethics, 70 Harv. L. REv. 657 (1957); Comment, Conflicts of Interest and the Former Government Attorney, 65 GEo. L.J. 1025 (1977).

5 "A Lawyer Should Preserve the Confidences and Secrets of a Client." Code, supra note 1, Canon 4.

"Confidence" refers to information protected by the attorney-client privilege under applicable law, and "secret" refers to other information gained in the professional relationship that the client has requested be held inviolate or the disclosure of which would be embarrassing or would be likely to be detrimental to the client.

DR 4-101(A). See notes 33 \& 36 infra.

An attorney who represents party $A$ in a lawsuit in which the opposing party, $B$, is a current or former client, may misuse confidences or secrets obtained during his representation of $B$ to further $A^{\prime}$ s cause. See DR $4-101(B)(2)$. Such misuse of confidences or secrets is more likely when the attorney represents the two clients 
fessional judgment on their behalf; ${ }^{6}$ moreover, such dual representation may appear to be improper. ${ }^{7}$ To protect the adverse party and to promote the dignity of the legal profession, the court may disqualify ${ }^{8}$ the attorney.

As motions to disqualify have become more prevalent, ${ }^{9}$ however, courts have recognized that disqualification inevitably injures the abandoned client ${ }^{10}$ in the litigation. ${ }^{11}$ Not only does disqualification deprive him of counsel of his choice, but it compels him to relegate his case to an attorney who is unfamiliar with the circumstances and legal issues. ${ }^{12}$ Moreover, it forces him to bear the

in related matters, because it is more likely that $B$ 's confidences can help $A$. Thus, when the matters are substantially related, courts presume that the attorney has learned confidences from $B$ that can help $A$. See, e.g., T. C. Theatre Corp. v. Warner Bros. Pictures, Inc., 113 F. Supp. 265, 268 (S.D.N.Y. 1953); see also notes 40-44 \& 108-09 infra \& accompanying text. In view of the proscription embodied in Canon 9, see note 7 infra, client $B$ typically will be a former rather than a present client.

6 "A Lawyer Should Exercise Independent Professional Judgment on Behalf of a Client." CoDE, supra note 1, Canon 5. Canon 5 concerns the attorney's ability to represent a client when he may be influenced by personal interests or the interests of others. See EC 5-1. These considerations are most relevant when an attorney is engaged in simultaneous representation, because his obligation to one client may temper his representation of the other. See, e.g., Westinghouse Elec. Corp. v. Gulf Oil Corp., 588 F.2d 221, 229 (7th Cir. 1978). See generally text accompanying notes $46-59$ infra.

7 "A Lawyer Should Avoid Even the Appearance of Professional Impropriety." Code, supra note 1, Canon 9. The attorney's obligation to promote the honor and integrity of the legal profession is threatened by conduct which may appear to laymen to be improper. E.g., EC's 9-2 \& 9-6. See generally text accompanying notes $61-73$ infra.

8 See E.F. Hutton \& Co. v. Brown, 305 F. Supp. 371, 398 (S.D. Tex. 1969); B.U. L. REv. Note, supra note 1, at 61. See generally B.U. L. REv. Note, supra note 1; Note, Disqualification of Attorneys for Representing Interests Adverse to Former Clients, 64 YaxE L.J. 917 (1955). Although an attorney may be disqualified for many reasons, e.g., DRs 5-101 to 5-104, 6-101, 7-101 to 7-110, 9-102, this Comment considers only those occasions in which disqualification is grounded upon representation of clients whose interests are in conflict or are potentially adverse.

9 See Aetna Cas. \& Sur. Co. v. United States, 570 F.2d 1197, 1202 (4th Cir.), cert. denied, 99 S. Ct. 87 (1978).

10 This Comment will use the term "abandoned client" to refer to the party whose attorney was disqualified, and who later requests that the disqualified attorney's work product be made available to substitute counsel. See generally notes 16-18 infra.

The "disqualifying party" is the party who has successfully moved for disqualification and who later opposes the work product request.

11 See, e.g., Board of Educ. v. Nyquist, $590 \mathrm{F.2d} 1241,1246$ (2d Cir. 1979); W.T. Grant Co. v. Haines, 531 F.2d 671, 677 (2d Cir. 1976).

12 The effects of court ordered disqualification are detailed in B.U. L. REv. Note, supra note 1 , at 65 . The severity of the damage done to the abandoned client depends in large part upon the complexity of the factual and legal issues involved, and the stage to which the litigation has progressed. When disqualification occurs in a complex case, or at an advanced stage of the lawsuit, the subsequent attorney may be unable to absorb adequately the nuances of the legal and 
additional expense of súccessor counsel's fee.13 Hence, courts are now becoming more reluctant to disqualify attorneys. ${ }^{14}$ Indeed, even when attorneys are disqualified, courts are receptive to the efforts of abandoned clients to ameliorate the detrimental effects of the disqualification..$^{15}$

One approach which the abandoned client may take is to move that the written work of the disqualified attorney be made available to substitute counsel. ${ }^{16}$ Typically, the abandoned client will apprise the court of the importance of this written work to successor counsel's familiarization with the case. He will argue that the motion must be granted to avoid the expensive and time-consuming process of duplicating the written work. ${ }^{17}$ The opposing party normally will respond that granting the motion would undermine the effectiveness and defeat the purpose of the disqualification order. ${ }^{18}$

The question of the availability of the written work product ${ }^{19}$ of an attorney who is disqualified because of dual representation was

factual matters involved. See, e.g., Government of India v. Cook Indus., Inc., 569 F.2d 737, 739 (2d Cir. 1978); W.T. Grant Co. v. Haines, 531 F.2d 671, 677 (2d Cir. 1976); Westinghouse Elec. Corp. v. Rio Algom Ltd., 448 F. Supp. 1284, 1306 (N.D. IIl.), rev'd in part sub nom. Westinghouse Elec. Corp. v. Kerr-McGee Corp., 580 F.2d 1311 (7th Cir.), cert. denied, 99 S. Ct. 353 (1978), rev'd in part on other grounds sub nom. Westinghouse Elec. Corp. v. Gulf Oil Corp., 588 F.2d 221 (7th Cir. 1978). See text accompanying notes 139-44 infra.

13 See cases cited in note 12 supra.

14 See, e.g., Board of Educ. v. Nyquist, 590 F.2d 1241, 1246 (2d Cir. 1979).

15 See, e.g., Norman Norell, Inc. v. Federated Dep't Stores, Inc., 450 F. Supp. 127, 130-3I (S.D.N.Y. 1978) (attorney, disqualified pursuant to DR 5-101(B)'s lawyer-witness prohibition, permitted to remain on the case until the trial).

${ }^{10} \mathrm{~A}$ client who makes such a request is likely to ask the court to permit the disqualified attorney to explain the contents of that written work to subsequent counsel. See, e.g., First Wis. Mortgage Trust v. First Wis. Corp., 74 F.R.D. 625 (E.D. Wis. 1977), rev'd, 584 F.2d 201 (7th Cir. 1978) (en banc). The scope of this Comment is restricted to the question of the availability of the written work of the disqualified attorney.

17 See Brief for Appellants at 34-35, First Wis. Mortgage Trust v. First Wis. Corp., 571 F.2d 390 (7th Cir. 1978).

18 Brief for Appellee at 16-17, First Wis. Mortgage Trust v. First Wis. Corp., 571 F.2d 390 (7th Cir. 1978) (quoting First Wis. Mortgage Trust v. First Wis. Corp., 74 F.R.D. 625, 627 (E.D. Wis. 1977), rev'd, 584 F.2d 201 (7th Cir. 1978) (en banc)).

19 The term "work product" is used in this Comment to comprise all written documents an attorney produces in preparation for, investigation of, and during the course of a lawsuit.

Since Hickman v. Taylor, 329 U.S. 495 (1947), an attorney's work product, more broadly defined, has enjoyed a limited immunity from discovery, now embodied in FED. $\mathrm{R}$ Crv. P. 26(b) (3). See note 125 infra. In this context, there is extensive case law on work products. See generally Annot., 35 A.L.R.3d 412 (1971). 
squarely confronted, for the first time, in First Wisconsin Mortgage Trust v. First Wisconsin Gorp. ${ }^{20}$ The Court of Appeals for the Seventh Circuit sitting en banc, reversing decisions of a three-judge circuit panel ${ }^{21}$ and the district court, ${ }^{22}$ held that the work product is not prohibited per se from being made available to the substitute attorney. ${ }^{23}$ Under the court's approach, availability would be determined on a case-by-case basis by the trial judge, who "should be satisfied that there is no taint of confidentiality or other improper advantage gained from the dual representation." 24 The court placed the burden on the disqualifying party ${ }^{25}$ to point to actual confidences or secrets or other improper advantages which might be used against it if the work product motion were granted. ${ }^{26}$

This Comment will show that this approach to the availability of the work product is improper. ${ }^{27}$ It is impracticable because it requires the trial court to spend considerable time examining voluminous documents which would be unlikely to reveal confidential information contained in, or used in the preparation of,

2074 F.R.D. 625 (E.D. Wis. 1977), rev'd, 584 F.2d 201 (7th Cir. 1978) (en banc). The propriety of extending a disqualification order to the work product of the attorney has been given summary consideration in a few cases, all of which resulted in the work product being made available. See IBM Corp. v. Levin, 579 F.2d 271, 283 (3d Cir. 1978); Fund of Funds, Ltd. v. Arthur Andersen \& Co., 567 F.2d 225, 236 (2d Cir. 1977); Allied Realty of St. Paul, Inc. v. Exchange Nat'l Bank, 408 F.2d 1099, 1101-02 (8th Cir. 1969), cert. denied, 396 U.S. 823 (1969); Little Rock School Dist. v. Borden, Inc., 1979-1 Trade CaSEs (CCH) [ 62,568 (E.D. Ark. April 5, 1979); Canadian Gulf Lines, Inc. v. Triton Int'l Carriers, Ltd., 434 F. Supp. 691, 695-97 (D. Conn. 1976); E.F. Hutton \& Co. v. Brown, 305 F. Supp. 371, 400-01 (S.D. Tex. 1969).

21571 F.2d 390 (7th Cir. 1978).

2274 F.R.D. 625 (E.D. Wis. 1977).

23584 F.2d 201, 204 (7th Cir. 1978).

24 Id. 211 n.6. The disqualification occurred when the law firm which had represented both First Wisconsin Mortgage Trust and First Wisconsin Corporation (as well as the two other parties joined as defendants) as general counsel, sought to represent First Wisconsin Corporation in a securities laws action brought against it by First Wisconsin Mortgage Trust. The firm had advised both principal parties, for example, on tax matters, and advised First Wisconsin Corporation on the creation of the trust. Thus, the firm aided in structuring the trust and in loan transactions involving both parties. Id. 202-03. The court decided that since the requested work product, summaries of loan files, prepared by the disqualified law firm for First Wisconsin Corporation for use in the litigation, did not contain any confidential information, id. 204, it should be made available to successor counsel.

25 See note 10 supra.

${ }^{26}$ See First Wis. Mortgage Trust v. First Wis. Corp., 584 F.2d 201, 209.

27 See generally text accompanying notes 102-44 infra. 
the work product. ${ }^{28}$ Further, the burden placed on the disqualifying party is unjustified in the light of ethical principles which have guided the courts. ${ }^{29}$

The purpose of this Comment is to devise a standard of availability for the work product of the disqualified attorney. This standard must be comprehensive, ${ }^{30}$ workable, and consistent with the ethical principles that guide courts in dual representation cases. Availability should be a function of the ethical obligation that disqualification was intended to enforce. Unless denial of the work product request is also necessary to enforce that obligation, the court should make the work product available to subsequent counsel.

Initially, the Comment will examine the usual grounds for disqualification for dual representation and the purpose served by the corresponding remedies. The Comment will then analyze the relationship between the availability of the work product and the ground for the disqualification. It concludes that the court should authorize the turnover of the work product unless the disqualification is grounded on the possibility that the disqualified attorney would use confidences or secrets to the detriment of the disqualifying party. 31

When the disqualification is based on that possibility, the court should employ a balancing approach: only if the possibility that confidences or secrets will be used against the disqualifying party outweighs the deleterious effects of unavailability on the abandoned client should the court deny the work product request. Finally, the Comment will apply this balancing analysis to First Wisconsin, ${ }^{32}$ concluding that the court reached the proper result.

28 See text accompanying notes 112-21 infra.

29 First Wis. Mortgage Trust v. First Wis. Corp., 584 F.2d 201, 211 (Castle, J., concurring in part and dissenting in part); see notes 117-21 infra \& accompanying text. Indeed, while the majority gave reasons for rejecting a per se rule, id. 208-09, it made no effort to justify its extraordinarily flexible standard.

30 First Wisconsin is limited to disqualifications based on Canon 4. For a discussion, in the context of First Wisconsin, of disqualification and access to work product when the disqualified attorney represented multiple parties who became adverse, see Note, Attorney Disqualification and Access to Work Product: Toward a Principled Rule, 63 ConNerr L. Rev. 1054 (1978) [hereinafter cited as Access to Work Product]. See also Comment, Attorney Work Product-New Counsel May Be Granted Access to Predisqualification Work Product of Prior Counsel, 54 Norre DaMe LaW. 544 (1979) [hereinafter cited as Attorney Work Product]; 32 Vand. L. Rev. 819 (1979) [hereinafter cited as VAND. L. REv.].

This Comment will examine all grounds for disqualification for dual representation: Canons 4, 5, and 9.

31 See text accompanying notes 74-101, infra.

1978) (en banc). 


\section{Purpose Behind Disqualification Under Canons 4,5 , AND 9}

\section{A. Canon 4-Preservation of Confidences and Secrets ${ }^{33}$}

Canon $4^{34}$ embodies the principle that the useful relation between attorney and client depends on full freedom and honesty of communication between them. ${ }^{35}$ For the client to feel free to relate all information necessary for effective representation, he must be assured that information that may be detrimental to him, or that he would not want generally known, will not be disclosed by the attorney. ${ }^{36}$ Consequently, the attorney is foreclosed from ever revealing the information confided in him. ${ }^{37}$

That attorneys are obligated to nondisclosure encourages the public to confide in them and to rely on the adversary system to

33 See generally note 5 supra. Disqualifications for dual representation are often grounded on some combination of the three canons to be discussed in this Comment. For purposes of illustration, however, it is useful to focus on each canon as the sole ground for disqualification.

This Comment treats "confidences" and "secrets" as having the same ethical implications. See ECs 4-1 to 4-6; DR 4-101; note 36 infra. For one possible distinction between "secrets" and "confidences," with resulting effects on disqualification and work product availability, see Access to Work Product, supra note 30.

34 "A Lawyer Should Preserve the Confidences and Secrets of a Client."

Canon 4 derives from Canons 6 and 37 of the old canons of ethics. CANons, supra note 1 .

Canon 6 reads: "The obligation to represent the client with undivided fidelity and not to divulge his secrets or confidences forbids also the subsequent acceptance of retainers or employment from others in matters adversely affecting any interest of the client with respect to which confidence has been reposed."

Canon 37 reads:

It is the duty of a lawyer to preserve his client's confidences. This duty outlasts the lawyer's employment, and extends as well to his employees; and neither of them should accept employment which involves or may involve the disclosure or use of these confidences, either for the private advantage of the lawyer or his employees or to the disadvantage of the client, without his knowledge and consent, and even though there are other available sources of such information. A lawyer should not continue employment when he discovers that this obligation prevents the performance of his full duty to his former or to his new client.

35 See, e.g., EC 4-1; W.H. TAFr, ETHICS IN SERvice 31-32 (1915); Elson, Responsibilities to the Client, in Professtonal Responsmitity, supra note 4, at 84 .

36 See ABA Comm. on Professional Ethics, Opinions, No. 91 (1933). Accordingly, the information protected from disclosure by Canon 4 is not confined to that protected by the attorney-client privilege but includes all information imparted by the client that he would not want to be revealed. See ECs 4-1 to 4-6; DR 4-101. See also notes 5 \& 33 supra. Moreover, this protection from disclosure is not expunged even where the information is part of the public record or available from other sources. EC 4-4. See H. Drinken, Legal Etrics 135 (1953).

37 DR 1-101(B). The attorney's obligation to preserve the confidences and secrets of a client continues after their professional relationship terminates. EC 4-6. See In re Boone, 83 F. 944, 953 (C.C.N.D. Cal. 1897). There are certain circum- 
resolve legal problems. ${ }^{88}$ When an attorney who breaches this obligation to his client is disqualified, the public's trust in the profession and system is reinforced. If the disqualification arises out of dual representation, however, it is intended to serve a more immediate purpose-insuring fundamental fairness in the judicial process by prohibiting the use of a client's secrets or confidences against his interests. ${ }^{39}$

Although the way an attorney uses secrets or confidences of a former client may be obvious in some cases, it is often too subtle to be perceived by a court. ${ }^{40}$ Indeed, an attorney may unconsciously transform such information into a disadvantage for the prior client. ${ }^{41}$ Thus, courts do not require the former client to point to specific confidences or secrets which may be used against him. ${ }^{42} \mathrm{He}$ is obligated to show only that there is a possibility that any confidences may be used against him. ${ }^{43}$ This possibility presumably outweighs

stances, however, under which the attorney may disclose confidences or secrets of a client. See DR 4-101(C). These are not relevant to the issues discussed in this Comment.

38 See Baird v. Koerner, 279 F.2d 623, 629-30 (9th Cir. 1960). See generally R. WISE, LEgaL ETHICS 160 (1966).

39 City of Cleveland v. Cleveland Elec. Illuminating Co., 440 F. Supp. 193, 206 (N.D. Ohio), affd mem., 573 F.2d 1310 (6th Cir. 1977), cert. denied, 435 U.S. 996 (1978); see B.U. L. REv. Note, supra note 1, at 64. DR 4-101(B)(2) prohibits an attorney from knowingly using a confidence or secret of his client to the client's disadvantage.

For example, if an attorney involved in litigation against a former client uses information acquired in the earlier representation to gain an advantage for his present client, the former client's rights would be clearly prejudiced. Information he disclosed on the assumption that it would not be used for purposes other than his representation would be used to his detriment. In such a case, the former client could be protected by such misuse only if the attorney is disqualified.

40 See Emle Indus., Inc. v. Patentex, Inc., 478 F.2d 562, 571 (2d Cir. 1973); see notes 117-21 infra \& accompanying text.

41 Emle Indus., Inc. v. Patentex, Inc., 478 F.2d 562, 571 (2d Cir. 1973).

42 To require the former client to point to specific confidences and secrets would compel him to disclose the very matters he seeks to preserve. Id.

$43 \mathrm{Id}$. The former client is required, rather, to show that

the matters embraced within the pending suit wherein his former attorney appears on behalf of his adversary are substantially related to the matters or cause of action wherein the attorney previously represented him . . . . The Court will assume that during the course of the former representation confidences were disclosed to the attorney bearing on the subject matter of the representation.

T.C. Theatre Corp. v. Warner Bros. Pictures, Inc., 113 F. Supp. 265, 268 (S.D.N.Y. 1953).

Some courts have taken issue with this irrebuttable presumption that, if the matters are substantially related, then information bearing on the present litigation was disclosed to the attorney by the former client. See City of Cleveland v. Cleveland Elec. Illuminating Co., 440 F. Supp. 193, 209 (N.D. Ohio), affd mem., 573 F.2d 1310 (6th Cir. 1977), cert. denied, 435 U.S. 996 (1978); Canadian Gulf Linés, Inc. v. Triton Int'l Carriers, Ltd., 434 F. Supp. 691 (D. Conn. 1976); of. 
the adverse effects of disqualification on the present client. ${ }^{44}$. Disqualification under Canon 4 in the context of dual representation, then, serves two purposes. First, and most important, it protects the rights of the party seeking disqualification. ${ }^{45}$ Second, it maintains public confidence in the legal system and profession.

\section{B. Canon 5-Exercise of Independent Professional Judgment}

Canon $5^{46}$ concerns the attorney's duty to "determine his actions by the single criterion of what would best serve his client's interests." 47 It is grounded on the principle that the attorney's loyalty to his client will be compromised if he must reconcile the interests of one client with those of another. ${ }^{48}$ In essence, Canon 5

Novo Terapeutisk Laboratorium A/S v. Baxter Travenol Labs., Inc., 201 U.S.P.Q. (BNA) 642 (7th Cir. 1979) (inflexible irrebuttable presumptions could lead to unreasonable results under unforeseen circumstances); note 111 infra (strict interpretation of "substantial relationship"); note 129 infra (presumption rebuttable when applied to information learned from others in firm).

44 As courts have grown more aware of the deleterious effects of disqualification, some have begun to question this assumption. See Government of India v. Cook Indus., Inc., 569 F.2d 737 (2d Cir. 1978); Canadian Gulf Lines, Inc. v. Triton Int'l Carriers, Ltd., 434 F. Supp. 691, 694-97 (D. Conn. 1976); cf. Novo Terapeutisk Laboratorium A/S v. Baxter Travenol Labs., Inc., 201 U.S.P.Q. (BNA) 642 (7th Cir. 1979) (irrebuttable presumption may not always lead to proper balance). See also notes 12-13 supra \& accompanying text.

45 The primacy of this purpose is shown by the holding that when confidences will be used against a client, Canon 4 precludes his consent to that use; on the other hand, when they will not be used against him, his consent is effective. Contrast Westinghouse Elec. Corp. v. Gulf Oil Corp., 588 F.2d 221, 228-29 (7th Cir. 1978), with id. 229 n.9, and EC's 4-2 \& 4-5, DR 4-10I(C)(1). Consent can therefore cure any deleterious effect of the release of confidential information except for its use against the client. Thus, the client's protection is the primary purpose of Canon 4.

46"A Lawyer Should Exercise Independent Professional Judgment on Behalf of a Client." Canon 5 derives from Canon 6 of the Canons, supra note 1, which says:

It is unprofessional to represent conflicting interests, except by express consent of all concerned given after a full disclosure of the facts. Within the meaning of this canon, a lawyer represents conflicting interests when, in behalf of one client, it is his duty to contend for that which duty to another client requires him to oppose.

47 Weddington, A Fresh Approach To Preserving Independent JudgmentCanon 6 of the Proposed Code of Professional Responsibility, 11 AnIz. L. REv. 31, 34 (1969) (the final draft of the Code changed the designation of Canon 6 to Canon 5).

48 EC 5-1 declares:

The professional judgment of a lawyer should be exercised, within the bounds of the law, solely for the benefit of his client and free of compromising influences and loyalties. Neither his personal interests, the interests of other clients, nor the desires of third persons should be permitted to dilute his loyalty to his client.

The ethical considerations under Canon 5 are categorized by the interests which may affect an attorney's judgment: his personal interests, EC's 5-2 to 5-13; those 
promotes professional zeal: ${ }^{49}$. an attorney who is subject to conflicting interests is unlikely to devote himself fully to his client's cause. ${ }^{50}$ Moreover, he demeans the legal profession in the eyes of the public.51

In the context of dual representation, Canon 5 is most often implicated when an attorney engages in simultaneous representation. ${ }^{52}$ The attorney may temper his outside representation of the disqualifying party because of loyalties to his client in the present litigation..$^{53}$ Therefore, a Canon 5 violation is not determined by the relationship between the subject matters of the two representa-

of multiple clients, EC's 5-14 to 5-20; and the desires of third persons, EC's 5-21 to $5-24$.

49 See Fred Weber, Inc. v. Shell Oil Co., 566 F.2d 602, 608 (8th Cir. 1877), cert. denied, 436 U.S. 905 (1978). On its face, Canon 7, "A Lawyer Should Represent a Client Zealously Within the Bounds of the Law," seems to be more central to this purpose. Its concern, however, is with the attorney's responsibility to provide the client with complete counsel and advice, enabling him to make an informed choice on the course of conduct he will follow. Monroe H. Freedman, Personal Responsibility in a Professional System, Address at the Pope John XXIII Lecture at Catholic University (Oct. 28, 1977), reprinted in 27 CATE. U. L. REv. 191, 200 (1978). Although Canons 5 and 7 do overlap in the context of dual representation, Canon 5, not Canon 7, has been relied upon by the courts.

50 Westinghouse Elec. Corp. v. Gulf Oil Corp., 588 F.2d 221, 229 (7th Cir. 1978). As the Committee on Ethics \& Professional Responsibility stated: "The Disciplinary Rules of Canon 5 bring into professional regulation, and with some specificity, the ancient maxim that one cannot serve two masters." ABA CoMn. on Etrics \& Professional Responsmility, Formal Opinion No. 342 at 2 (1975) (footnote omitted).

51 The duty of loyalty is undermined because the client feels that the attorney has failed to abide by his unspoken commitment to enforce the client's rights to the fullest extent. At the same time, the public loses respect for the profession, because it believes that attorneys are more concerned with financial benefit than the needs of their clients. See, e.g., Grievance Comm. of the Bar of Hartford County v. Rottner, 152 Conn. 59, 65, 203 A.2d 82, 84 (1964).

52 See A. Kaufman, Problems in Professional Responsibmity 46 (1976); note 2 supra \& accompanying text. In successive representation, the interest which may impair the attorney's independent professional judgment is that of a former client rather than a present client. Thus, the attorney is less likely to be influenced in his representation than if the adversary party were a current client.

In successive representation, Canon 4 is more important. See A. Kaurman, supra at 45 . When Canon 5 is implicated in cases of successive representation, it is usually in addition to Canon 4. See, e.g., Fred Weber, Inc. v. Shell Oil Co., 566 F.2d 602, 606 (8th Cir. 1977), cert. denied, 436 U.S. 905 (1978); Moritz v. Medical Protection Co., 428 F. Supp. 865 (W.D. Wis. 1977); note 55 infra.

53 IBM Corp. v. Levin, 579 F.2d 271, 280 (3d Cir. 1978). For example, the attorney might represent $A$ against $B$ in an antitrust suit, while representing $B$ in an unrelated labor matter. $B$ might move to disqualify in the antitrust suit. fearing that the attorney's loyalty to $A$ may affect his representation of $B$ in the labor matter. On the other hand, if $A$ fears that the attorney will temper his representation of him in the antitrust suit, he could simply discharge him. (A cannot move for disqualification in the labor matter because he is not a party.) Indeed, if $A$ knew, before the litigation, of the attorney's relationship with $B$ and was apprehensive about its effect on the antitrust suit, $A$ could have hired a different attomey. 
tions; ${ }^{54}$ instead, the attorney is disqualified under DR 5-105 ${ }^{55}$ when "there will be ... [an] actual or apparent conflict in loyalties or diminution in the vigor of his representation," 56 if he continues to participate in the lawsuit. Thus, the primary purpose of disqualification under Canon 5 is to insure loyalty to the client. Unlike Canon 4, however, Canon 5 does not protect the disqualifying party's interests in the current litigation. ${ }^{57}$

Another purpose behind disqualification under Canon 5 is to maintain public confidence in the loyalty and integrity of the bar. ${ }^{58}$ The standard for disqualification under Canon 5, with its emphasis

64 Westinghouse Elec. Corp. v. Gulf Oil Corp., 588 F.2d 221, 229 (7th Cir. 1978); IBM Corp. v. Levin, 579 F.2d 271, 279-80 (3d Cir. 1978). There need be no relationship between the representations, because "[ $t]$ he propriety of this conduct must be measured not so much against the similarities in litigation, as against the duty of undivided loyalty which an attorney owes to each of his clients." Cinema 5, Ltd. v. Cinerama, Inc., 528 F.2d 1384, 1386 (2d Cir. 1976); see id. 1387.

55 DR 5-105(B) states:

A lawyer shall not continue multiple employment if the exercise of his independent professional judgment in behalf of a client will be or is likely to be adversely affected by his representation of another client or if it would be likely to involve him in representing differing interests, except to the extent permitted under DR 5-105(C).

“'Differing interests' include every interest that will adversely affect either the judgment or the loyalty of a lawyer to a client, whether it be a conflicting, inconsistent, diverse, or other interest." CODE, supra note 1 , Definitions.

56 Cinema 5, Ltd. v. Cinerama, Inc., 528 F.2d 1384, 1387 (2d Cir. 1976) (emphasis in original). The prohibition against an appearance of impropriety is embodied in Canon 9. See text accompanying notes 61-73, infra.

Some courts have used the Canon 4 "substantial relationship" test, see note 43 supra, in Canon 5 successive representation cases. When Canon 4 also has been implicated, e.g., City of Cleveland v. Cleveland Elec. Illuminating Co., 440 F. Supp. 193, 205-08 (N.D. Ohio), aff'd mem., 573 F.2d 1310 (6th Cir. 1977), cert. denied, 435 U.S. 996 (1978), reliance on the "substantial relationship" standard as the "test for disqualification" may be justified; the court presumes that a breach of the Canon 4 duty to preserve confidences and secrets is necessarily a breach of the Canon 5 duty of undivided loyalty. See Fund of Funds, Ltd. v. Arthur Andersen \& Co., 567 F.2d 225, 234 n.17 (2d Cir. 1977). However, when the court rejects a Canon 4 claim and still utilizes the "substantial relationship" test, e.g., Moritz v. Medical Protective Co., 428 F. Supp. 865, 875 (W.D. Wis. 1977), it is using an improper standard. Unlike a Canon 4 situation, there is no reason to presume that a substantial relationship between the two representations will cause a breach of loyalty under Canon 5. Cf. note 43 supra \& accompanying text (reasons for substantial relationship presumption under Canon 4).

57 When the disqualifying party is a former client there is no danger, in the Canon 5 context, that his representation will be impaired. In this situation, the primary purpose of disqualification is maintaining public confidence in the loyalty and integrity of the bar. See text accompanying notes 58-59 infra.

58 See IBM Corp. v. Levin, 579 F.2d 271, 283 (3d Cir. 1978). The assumption in the Canon 5 case, as under Canon 4, is that the need for the disqualification outweighs the detrimental effect to the abandoned client. E.g., City of Cleveland v. Cleveland Elec. Illuminating Co., 440 F. Supp. 193, 195-96 (N.D. Ohio 1977), affd mem., 573 F.2d 1310 (6th Cir. 1977), cert. denied, 435 U.S. 996 (1978): 
on actual or apparent conflict in loyalties, ${ }^{69}$ is evidence that the public perception of the legal profession underlies the remedy. Hence, the attorney who is disqualified under Canon 5 is an example of the absolute fidelity of the bar. Still, although the disqualifying party's confidence in the loyalty of members of the legal profession may be restored by the disqualification, his position in the present litigation will be unaffected. ${ }^{.0}$ Therefore, while Canons 4 and 5 both constitute grounds for disqualification in the context of dual representation, the purpose served by their respective remedies is different.

\section{Canon 9-Appearance of Impropriety}

In contrast to the proscriptions of Canons 4 and 5, Canon 9's declaration that "[a] [1] awyer [s] hould [a]void [e]ven the [a]ppearance of [p]rofessional [i]mpropriety" relates to all aspects of an attorney's conduct. ${ }^{81}$ Implicit in the old Canons of Professional Ethics, ${ }^{62}$ the admonition of Canon 9 is particularly applicable to situations of dual representation. ${ }^{63}$ Canon 9 reflects the bar's concern that some attorney conduct which is in fact ethical may appear unethical to a layman, ${ }^{64}$ undermining public confidence in the legal profession and judicial system. ${ }^{\text {as }}$

59 See note 55 supra \& accompanying text. In dual representation situations, Canons 5 and 9 serve essentially the same purpose. See text accompanying notes 65-66 infra. In other situations, however, the purpose of Canon 5 is closer to that of Canon 4; that is, it assures that neither party to the litigation is prejudiced by the actions of an attorney. See, e.g., DR 5-102(B) (counsel testifying against his client).

60 See note 57 supra \& accompanying text.

61 See, e.g., Fred Weber, Inc. v. Shell Oil Co., 566 F.2d 602, 609 (8th Cir. 1977), cert. denied, 436 U.S. 905 (1978); Westinghouse Elec. Corp. v. Rio Algom Ltd., 448 F. Supp. 1284, 1304 (N.D. Ill.), rev'd in part on other grounds sub nom. Westinghouse Elec. Corp. v. Kerr-McGee Corp., 580 F.2d 1311 (7th Cir.), cert. denied, 99 S. Ct. 353 (1978), rev'd in part on other grounds sub nom. Westinghouse Elec. Corp. v. Gulf Oil Corp., 588 F.2d 221 (7th Cir. 1978). EC 9-2 provides: "When explicit ethical guidance does not exist, a lawyer should determine his conduct by acting in a manner that promotes public confidence in the integrity and efficiency of the legal system and the legal profession."

62 See, e.g., Canons, supra note 1, Nos. 6, 36, \& 37; Kaufman, supra note 4 , at 659. The command "abstain from all appearance of evil" is found in 1 Thessalonians 5:22.

63 See Aronson, Conflict of Interest, 52 WASH. L. REv. 807, 810 (1977).

64 Woods v. Covington County Bank, 537 F.2d 804, 813 (5th Cir. 1976); see EC 9-2; ABA Comom. on Professional Ethits, Informal Opinton No. 885 (1965).

65 Woods v. Covington County Bank, 537 F.2d 804, 813 (5th Cir. 1976); see Aronson, Conflict of Interest, 52 Wash. L. Rev. 807, 810 (1977); cf. Kramer v. Scientific Instrument Co., 534 F.2d 1085, 1088 (3d Cir. 1976) ("II]mportant as it was that people should get justice, it was even more important that they should 
Although Canons 5 and 9 can serve the same purpose in the dual representation context, there are differences in their applicability. Whereas Canon 5 (as well as Canon 4) refers to the attorney's obligation to his client, Canon 9 refers only to his duty to his profession. ${ }^{6 \theta}$ Moreover, as a rationale for disqualification, Canon 9 is weaker than either Canon 4 or 5 because no unethical act or wrongdoing need occur for it to be invoked..$^{67}$ This tenuous basis is compounded in the case of disqualification for dual representation ${ }^{88}$ because none of the Canon 9 disciplinary rules is implicated. ${ }^{69}$ Thus, disqualification is grounded on a literal reading of the Canon, language "too vague . . . to be useful." 7o Hence, courts caution against indiscriminate use of Canon 9 as a ground for disqualification for dual representation. ${ }^{11}$

Consequently, when courts invoke Canon 9 in dual representation cases, they are reluctant to assume that the benefits to be derived from disqualification outweigh the harm to the abandoned client. $^{72}$ Instead, they require that the likelihood of public suspi-

be made to feel and see that they were getting it.") (quoting Lord Herschell in 2 J. B. Atrax, Victorian Chancellors 460 (1908)).

66 EC 0-6 states:

Every lawyer owes a solemn duty to uphold the integrity and honor of his profession; to encourage respect for the law and for the courts and judges thereof; . . . to conduct himself so as to reflect credit on the legal profession and to inspire the confidence, respect, and trust of his clients and of the public; and to strive to avoid not only professional impropriety but also the appearance of impropriety.

67 Fred Weber, Inc. v. Shell Oil Co., 566 F.2d 602, 609 (8th Cir. 1977), cert. denied, 436 U.S. 905 (1978). There need be only an appearance of impropriety for Canon 9 to be contravened.

68 Unlike Canons 4 and 5, Canon 9 is applied with equal frequency to successive and simultaneous representation. In view of its flimsy ethical basis, however, Canon 9 is not often the sole ground for disqualification. See text accompanying notes 66 \& 67 supra and 69-73 infra.

69 The only disciplinary rules under Canon 9 are DR 9-101, "Avoiding Even the Appearance of Impropriety," and DR 9-102, "Preserving Identity of Funds and Property of a Client." Neither relates to dual representation.

70 ABA Comam. ON Etmics \& Professional Responsmitrty, Formal Opinion No. 342 at 5 n.17 (1975).

71 E.g., Board of Educ. v. Nyquist, 590 F.2d 1241, 1247 (2d Cir. 1979) ("[W]hen there is no claim that the trial will be tainted, appearance of impropriety is simply too slender a reed on which to rest a disqualification order except in the rarest cases."); City of Cleveland v. Cleveland Elec. Illuminating Co., 440 F. Supp. 193, 205 (N.D. Ohio), aff'd mem., 573 F.2d 1310 (6th Cir. 1977), cert. denied, 435 U.S. 996 (1978). See, e.g., Fred Weber, Inc. v. Shell Oil Co., 566 F.2d 602, 609 (8th Cir. 1977), cert. denied, 436 U.S. 905 (1978); International Elec. Corp. v. Flanzer, 527 F.2d 1288, 1295 (2d Cir. 1975); Silver Chrysler Plymouth, Inc. v. Chrysler Motors Corp., 518 F.2d 751, 757 (2d Cir. 1975).

72 When Canon 9 has been invoked in other contexts, however, courts have been more apt to approve of this assumption. See Zylstra v. Safeway Stores, Inc., 578 F.2d 102, 104 (5th Cir. 1978); Kramer v. Scientific Control Corp., 534 F.2d 1085, 1092-93 (3d Cir. 1976), cert. denied, 429 U.S. 830 (1977). 
cion or obloquy outweigh the social interests which would be served by the attorney's continued participation in the case. ${ }^{73}$ Thus, prevention of suspicion or obloquy is the exclusive purpose behind disqualification under Canon 9.

\section{.II. Relationship Between Purpose Behind Disqualification and Avallability of Work Product}

When an attorney is disqualified for dual representation, courts assume, implicitly ${ }^{74}$ or explicitly, ${ }^{75}$ that the need to prevent the evils which triggered disqualification outweighs the adverse effects of disqualification on the abandoned client. ${ }^{76}$ The work product is concededly the fruit of the representation for which counsel was disqualified. ${ }^{77}$ If the court denies a motion to make the work product available, it implicitly uses the same balance that underlay the disqualification decision. However, if disqualification alone eliminates the evils which necessitated it, then denial of the work product request can have no further benefits.

Denial of the work product motion also increases substantially the harm to the abandoned client. Whereas disqualification limits prospectively the abandoned client's choice of counsel, denial of the work product deprives him of services already rendered and paid for. The abandoned client suffers the expense and delay of duplicating the work product. ${ }^{78} \mathrm{He}$ also risks being deprived of effective assistance of counsel because successor counsel may be unable to duplicate important parts of the work product. ${ }^{79}$

In these circumstances, the further adverse effects on the abandoned client outweigh the reasons for denial of the work product: denial is unjustified. Only if denying the work product helps to accomplish the purpose behind disqualification should the abandoned client be forced to bear the burdens of delay, expense, and possibly inadequate representation. ${ }^{80}$

73 Woods v. Covington County Bank, 537 F.2d 804, 813 n.12 (5th Cir. 1976). Moreover, there must also be a reasonable possibility that some specifically identifiable impropriety did occur. See generally Note, Appearance of Impropriety as the Sole Ground for Disqualification, 31 U. Mramr L. Rev. 1516 (1977).

74 See text accompanying note 44 supra (Canon 4); note 58 supra (Canon 5).

75 See text accompanying note 73 supra (Canon 9).

76 See text accompanying notes 12-13 supra.

77 See Brief for Appellants, supra note 17, at 30.

78 See text accompanying notes 131-38 infra.

79 See text accompanying notes $139-44$ infra.

80 Brief for Appellants, supra note 17, at 34; see text accompanying notes 139 44 infra. 


\section{A. Disqualification Under Canon 4}

Disqualification for dual representation under Canon 4 is primarily intended to insure that the disqualifying party's ${ }^{81}$ confidences and secrets will not be used to his detriment. ${ }^{82}$ Disqualification prevents the disqualified attorney from misusing confidences, but it neglects the problem of the work product: the work product may contain, or be a product of, confidential information. If the substitute attorney has access to a tainted work product, confidences may be used to the detriment of the disqualifying party, defeating the primary purpose of disqualification.

When a court disqualifies an attorney under Canon 4 , it assumes that the possibility of misuse of the disqualifying party's confidences and secrets outweighs the harm to the abandoned client. ${ }^{83}$ A motion to gain access to the work product of an already disqualified attorney, however, does not require adherence to this assumption. Disqualification substantially reduces the possibility of misuse of confidences: only those confidences which are embodied in the work product, rather than all those entrusted to disqualified counsel, can be misused. ${ }^{84}$ Furthermore, the substitute counsel may be unable to use confidences which are in the work product because they may be so deeply embedded that he cannot perceive them.

Nevertheless, granting the work product motion may possibly undermine the disqualification. Whether this possibility outweighs the harm to the abandoned client hinges on the facts of the individual case. ${ }^{85}$ Availability of the work product, therefore, must be determined by those facts. ${ }^{86}$

\section{B. Disqualification Under Canon 5}

Disqualification for dual representation under Canon 5 serves two purposes: preserving an attorney's loyalty to his client and pub-

81 The disqualifying party will likely be a former client. See note 5 supra.

82 See text accompanying notes 33-45 supra.

83 See note 44 supra \& accompanying text.

84 Disqualification eliminates, inter alia, unconscious misuse of secrets. Emle Indus., Inc. v. Patentex, Inc., 478 F.2d 562, 571 (2d Cir. 1973). See also text accompanying notes 107-30 infra.

85 See text accompanying notes 102-44 infra. In First Wisconsin, the threejudge panel, affirming the decision of the district court, decided that the work product should be per se precluded from being turned over to the successor attorney because availability would be inconsistent with the disqualification order under Canon 4. 571 F.2d 390, 396-98 (7th Cir. 1978). This decision was reversed en banc because such a per se rule fails to take into account the interests of the abandoned client as well as any peculiar factual variations. 584 F.2d 201, 204-11 (7th Cir. 1978).

${ }^{86}$ See generally text accompanying notes 102-44 infra. 
lic confidence in the bar. ${ }^{87}$ Denial of a work product motion enhances neither purpose and creates additional harm to the abandoned client. Therefore, when disqualification is based on a Canon 5 violation, the work product request should be granted.

When Canon 4 is violated, the danger requiring disqualification-possibility of misuse of confidences-may persist in the work product. In contrast, in a Canon 5 disqualification, this danger does not exist because the work product does not contain the conflict of loyalties that required the attorney's disqualification. The disqualifying party's claim, rather, is that the attorney's loyalty is diverted in an outside matter. ${ }^{88}$ Thus, denial of the request cannot enhance the first purpose behind Canon 5 disqualification.

At the same time, denial of the work product request does not enhance the second purpose of Canon 5 disqualification, preservation of public confidence by demonstrating that loyalty to clients is a fundamental responsibility of a lawyer. Once a lawyer is disqualified, it is extremely unlikely that public confidence will be significantly bolstered by denial of the work product motion. ${ }^{83}$ Unlike disqualification, denial of the work product request is essentially a penalty against the abandoned client: ${ }^{90}$ its effects are not felt by the disqualified attorney, the individual who has breached an obligation, because he is no longer involved in the case. Thus, although disqualification of the offending attorney may promote public confidence in the bar, denial of the work product motion does not further that end.

Indeed, by denying the work product motion when such a sanction serves no constructive purpose, the court may eviscerate its disqualification order. By compelling the abandoned client to pay an attorney to duplicate work already done, the court may create the very suspicion of the integrity of the legal profession that Canon 5 seeks to avoid.1 Moreover, the delays in litigation accompanying

87 See text accompanying notes 46-59 supra.

88 See note 53 supra \& accompanying text.

89 In First Wis. Mortgage Trust v. First Wis. Corp., 584 F.2d 201, 216 n.6 (7th Cir. 1978) (en banc) (Castle J., concurring in part and dissenting in part), the dissenting judges recognized that when an attorney is disqualified for simultaneous representation under Canon 5, the purpose of disqualification is not undermined by approval of a work product request.

00 Id. 208 (majority opinion).

91 In one survey, $68 \%$ of the respondents agreed that "[m]ost lawyers charge more for their services than they are worth." B. Curran, The Legal NEeds of. THE PuBLic 231 (1977) (joint ABA-American Bar Foundation survey). 
such duplication reinforce the public's perception of the legal system as inefficient. ${ }^{92}$

In a Canon 5 case, the adverse effects of denial of the work product motion clearly outweigh the support such denial may lend to the purpose behind the disqualification. Although there may be limited situations in which the court should deny a work product motion, ${ }^{93}$ the work product should be made available in the typical Canon 5 case.

\section{Disqualification Under Canon 9}

Disqualification for dual representation under Canon 9 is not a punishment for unethical action; rather, the court disqualifies the attorney because his conduct is vulnerable to misinterpretation which could disparage the bar in the eyes of the public. ${ }^{94}$ Consequently, courts disqualify an attorney under Canon 9 only if the possibility of public suspicion outweighs the adverse effects of disqualification..$^{95}$

When a client whose attorney has been disqualified under Canon 9 submits a work product request, the court must consider whether granting the request will increase the likelihood of public suspicion. Disqualification, however, all but eliminates this likelihood: if the attorney has appeared to act improperly, his expulsion from the case eliminates the cause of public obloquy. ${ }^{96}$

Although it has been argued that the likelihood of public suspicion can never be entirely erased unless the attorney's work product is also eliminated from the case, ${ }^{97}$ it is important to emphasize that the appearance of impropriety lies in the conduct of the attorney. By undertaking dual representation, he places himself in a position in which he appears to be doing something wrong. Because it is his position, and not the work he actually does, which gives rise to the disqualification, his disqualification alone should

92 The problem of delays in litigation is given thoughtful treatment in Lasker, The Court Crunch: A View From the Bench, 76 F.R.D. 245 (1977). See also note 132 infra.

93 In rare cases, the disqualifying party may be able to show that the work product may carry forward the ethical violation which caused disqualification. In these cases, the court should use the same balancing approach as for Canon 4. See note 104 and text accompanying notes 102-04 infra.

94 See text accompanying notes 64-73 supra.

95 Woods v. Covington County Bank, 537 F.2d 804, 813 n.12 (5th Cir. 1976); see notes 72 \& 73 supra \& accompanying text.

96 Brief for Appellants, supra note 17, at 33.

${ }^{97}$ First Wis. Mortgage Trust v. First Wis. Corp., 571 F.2d 390, 397 (7th Cir.), rev'd, 584 F.2d 201. (7th Cir. 1978) (en banc). 
suffice to extinguish that appearance. Still, if the substitute attorney appears to be acting improperly by using the work product, the likelihood of public suspicion may remain although the work product itself remains untainted.

Even if use of the work product does remotely contribute to the possibility of public suspicion, however, the harm to the abandoned client from denying the work product motion clearly outweighs that possibility. 98 The burden placed on the abandoned client when any work product request is denied is great; ${ }^{99}$ it would be manifestly unjust ${ }^{100}$ to impose this burden without adequate justification. Hence, in the typical Canon 9 case, the work product should be made available. ${ }^{101}$

\section{Proposed Standard for Availability of Work Product}

When the court determines whether to grant a work product motion, it strikes a balance between, on the one hand, the possible enhancement of both the disqualifying party's rights and the public's perception of the legal profession, and, on the other, the added harm to the abandoned client. Typically, when the work product motion follows a disqualification grounded on Canon 5 or 9, the interest of the abandoned client prevails. Because the work product in either case relates only insignificantly to the ethical obligation the attorney was disqualified for threatening, ${ }^{102}$ the court should create a presumption favoring the abandoned client; ${ }^{103}$ thus, the work product would normally be made available. ${ }^{104}$

98 It is important to recall that Canon 9 disqualification is not based on any actual misconduct of the attorney; rather, it is grounded on the appearance of unethical behavior. Therefore, such appearance should be strong to outweigh the harm where the attomey has done nothing wrong. See text accompanying notes 64-73 supra.

90 See text accompanying notes $131-44$ infra.

100 As Judge Gurfein stated in the context of a disqualification motion, "When we find an area of uncertainty, ... we must use our judicial process to make our own decision in the interests of justice to all concerned." J.P. Foley \& Co. v. Vanderbilt, 523 F.2d 1357, 1360 (2d Cir. 1975) (Gurfein, J., concurring).

101 Just as in Canon 5 cases, there may be exceptions. See note 104 and text accompanying notes 102-04 infra.

102 See text accompanying notes 87-101 supra.

103 Most presumptions arise because courts have recognized that "proof of fact $B$ renders the inference of the existence of fact $A$ so probable that it is sensible and time-saving to assume the truth of fact A until the adversary disproves it." C. MCCormucK, Handbook of THe LAW of Evidence $\$ 343$ (E. Cleary ed. 1972). Because it is so probable that, if the disqualification is grounded on Canon 5 or 9 , then the interests of the abandoned client prevail, the court should create such a presumption. The work product should usually be made available in these cases. But see note 104 infra.

104 The disqualifying party, of course, may attempt to rebut this presumption, but the possibility that he will succeed is remote. In light of the tenuous relation- 
On the contrary, when disqualification is grounded on Canon 4 , the possible prejudice to the disqualifying party's rights may outweigh the harm to the abandoned client. ${ }^{105}$ The court cannot presume that the balance favors the interests of one party; instead, the court should examine the facts in a case-by-case approach. ${ }^{106}$

\section{A. Likelihood That Confidences or Secrets Will Be Used Against Adverse Party}

Granting the work product motion harms the interests of the disqualifying party only if the work product contains confidences or secrets which will be used against him. Such harm will occur only if two other events have occurred. First, the abandoned client must have communicated confidences to the disqualified attorney relevant to the present litigation; second, those confidences must have found their way into the work product. ${ }^{107}$

\section{Relevance of the Presumed Confidences or Secrets to the Present Litigation}

In deciding whether the abandoned client communicated relevant confidences or secrets to the disqualified attorney, the court

ship between the work product motion and the public perception of the bar, see text accompanying notes 87-101 supra, the disqualifying party can show that the benefits flowing from a denial of the work product motion outweigh the detriments only by establishing that he will be prejudiced if the work product is turned over.

He might succeed, for example, if he demonstrates that even though the disqualification was not grounded on Canon 4, there remains a possibility that secrets or confidences will be used against him. If the court determines that this possibility exists, so that the disqualification could have been grounded on Canon 4 as well as Canon 5 or 9 , then the presumption is rebutted. The availability of the work product then turns on the ad hoc balancing approach used when Canon 4 is invoked. See text accompanying notes $105 \& 106$ infra.

105 See notes 81-86 supra.

108 For a suggested balancing approach to the issue of the attorney-client privilege, see Note, The Attormey-Client Privilege: Fixed Rules, Balancing, and Constitutional Entitlement, 91 HARv. L. Rev. 464, 473-87 (1977).

The need to balance arises in any case of disqualification in which the court invokes Canon 4, even when it is not the sole ground for disqualification. In such a case, the burden of proof is on the movant, but when the disqualification is based on Canon 5 or 9 , the burden shifts to the adverse party. See note 104 supra \& accompanying text.

107 This analysis omits a third step-the substitute attorney must actually use the confidences against the disqualifying party. The court should, however, omit this step from its factual analysis of the case because, practically, it cannot determine if this event will occur.

The court cannot tell if substitute counsel will actually discover any confidences which the work product contains because the court cannot inspect the work product. See notes 118-21 infra \& accompanying text. Furthermore, counsel's inclination to use confidences which he discovers in the work product, and the possibility that he will use them unconsciously, are too speculative: the court should simply assume that there is a constant probability that substitute counsel will find and use any confidences which are in the work product. 
must start with the "substantial relationship" test.108 In disqualifying the attorney under Canon 4, the court has decided that the disqualified attorney's representation of the disqualifying party relates so closely to the present litigation that the court must presume that pertinent confidences and secrets were communicated to the attorney. ${ }^{109}$

When considering a work product motion, the court should continue this analysis by focusing on similarities between the factual situations and legal issues involved in the two representations. ${ }^{110}$ As the relationship between the representations grows more substantial, the greater the relevance to the present litigation of the information presumed to have been imparted to the disqualified attorney. If the issues are identical (the attorney, for example, having literally switched sides), the information must be deemed highly pertinent to the present litigation. ${ }^{111}$

\section{Presence of Confidences and Secrets in Work Product}

The court must next evaluate the likelihood that such confidences or secrets are in the work product prepared by disqualified

108 See note 43 supra \& accompanying text.

109 See, e.g., T.C. Theatre Corp. v. Warner Bros. Pictures, Inc., 113 F. Supp. 265, 268 (S.D.N.Y. 1953). In his First Wisconsin opinion concurring in part and dissenting in part, Judge Castle suggests that the "substantial relationship" test be used to determine the availability of the work product, 584 F.2d at 215-16. He suggests that the mere possibility that secrets or confidences are contained in the work product and may, thus, be used to the detriment of the adverse party, calls for denial of the work product motion.

This view, however, fails to give adequate weight to the interest of the abandoned client. Having experienced the loss of counsel of his choice, he should not be compelled further to endure the harms stemming from denial of the work product motion without further justification. Indeed, by advocating the use of the same standard as that employed in deciding the disqualification question, Judge Castle fails to recognize the extent to which disqualification reduces the likelihood that confidences or secrets will be used to the detriment of the adverse party. See text accompanying notes 84-85 supra and text accompanying notes 112 \& 114 infra.

110 See generally Silver Chrysler Plymouth, Inc. v. Chrysler Motors Corp., 518 F.2d 751, 760 (2d Cir. 1975) (Adams, J., concurring) (discussing determinants of "substantial relationship").

111 In at least one circuit, consideration of the interests of the abandoned client has led to a strict interpretation of "substantial relationship." An attomey will not be disqualified unless the two representations involve virtually identical issues. Government of India v. Cook Indus., Inc., 569 F.2d 737, 739-40 (2d Cir. 1978). See also Silver Chrysler Plymouth, Inc. v. Chrysler Motors Corp., 518 F.2d 751, 754-56 (2d Cir. 1975); Canadian Gulf Lines, Inc. v. Triton Int'l Carriers, Ltd., 434 F. Supp. 691, 694 (D. Conn. 1976).

Where that is the rule, the court may assume, for purposes of the work product motion, that the relationship between the two representations is extremely close; hence, the confidences and secrets presumably passed from the disqualifying party to the disqualified attorney should be deemed highly relevant to the present litigation. 
counsel. The court presumes, for purposes of the disqualification order, that relevant secrets or confidences were obtained by the attorney from the disqualifying party. This does not mean, however, that the attorney inserted such information into his work product in the present litigation. ${ }^{112}$ Confidences and secrets may be retained by counsel in his mind without being translated into written materials. Indeed, even if counsel prepared those materials with the information in mind, the secrets and confidences may not actually appear within them; thus, it is probable that only the individual who produced the work product could associate the information with the various written materials. ${ }^{\mathbf{1 1 3}}$

This consideration, as well as the interests of the abandoned client, convinced the Seventh Circuit, rehearing First Wisconsin Mortgage Trust $v$. First Wisconsin Corp., ${ }^{114}$ to reject the presumption that relevant confidences and secrets are embodied in the work product. Rather, the court instructed the trial judge to examine the written materials to ascertain whether there is a "taint of confidentiality or other improper advantage" to the abandoned client within them. ${ }^{115}$

Furthermore, the court placed the burden on the disqualifying party to identify "specific confidential information" that may be used to his detriment.116 In requiring a showing of "specific confidential information," however, the court ignored the interests of the disqualifying party as well as considerations of practicability. Such a requirement compels the disqualifying party to reveal the very information he seeks to preserve. ${ }^{117}$ Preservation of confidences

112 See text accompanying note 84 supra.

113 Of course, there is always the possibility that, although specific secrets or confidences may not appear in the work product, the information that does appear is of the type that could have been written only by someone with knowledge of secrets or confidences. See VAND. L. Rev., supra note 30 , at 831 . For instance, although a discovery request may not itself contain secrets or confidences, the disqualified lawyer may have prepared the request, and listed the location of documents requested, as the result of knowledge of secrets or confidences. In that sense, the work product would be tainted and disqualification alone might not totally solve the problem. However, the point remains that such an eventuality is remote.

114584 F.2d 201 (7th Cir. 1978) (en banc).

115 Id. 211 n.6. Although the court acknowledges that "other improper advantage," id., may accrue if the work product is turned over to successor counsel, it gives no indication of what that advantage might be. The court does assert, however, that such advantage might arise "from the very fact of the knowledge and acquaintanceship acquired during the period of the prior representation." Id. 205. The implication is that the court is merely adverting to the secrets which are given the same protection under Canon 4 as are confidences. See definitions quoted in note 5 stpra.

116584 F.2d 201, 209.

117 Emle Indus., Inc. v. Patentex, Inc., 478 F.2d 562, 571 (2d Cir. 1973). 
and secrets is as important at the work product stage as it is at the disqualification stage. Courts do not require the disqualifying party to point to specific confidences when he seeks disqualification; ${ }^{118}$ neither should they at the work product stage.

Moreover, even if the disqualifying party were to identify confidences or secrets that might be used against him, it is unlikely that the trial judge, in examining the work product, could determine if it contained such confidences or secrets. 119 Such information is likely to be deeply embedded in the writings. Hence, documents containing secrets or confidences may appear innocuous to a trial judge whose familiarity with both the abandoned client, for whom the work product was prepared, and the disqualifying party, whose confidences and secrets may be embodied in the materials, is likely to be minimal. ${ }^{120}$

If the trial judge were able to study the documents exhaustively, of course, he might be able to discover deeply embedded confidences. However, the work product sought may consist of literally thousands of documents. Even a cursory examination of each document would require a huge amount of time. Thorough review of the work product, then, is an unrealistic burden for the trial judge. ${ }^{121}$ Hence, the constraints on judicial time and the

118 See, e.g., NCK Org. Ltd. v. Bregman, 542 F.2d 128, 134-35 (2d Cir. 1976); Emle Indus., Inc., v. Patentex, Inc., 478 F.2d 562, 571 (2d Cir. 1973); T.C. Theatre Corp. v. Wamer Bros. Pictures, Inc., 113 F. Supp. 265, 268-69 (S.D.N.Y. 1053); see also notes 43 \& 44 supra \& accompanying text.

The court in First Wis. Mortgage Trust v. First Wis. Corp., 584 F.2d 201 (7th Cir. 1978) (en banc), suggests that the trial court's examination of the work product could occur in camera. Id. 209, 211 n.6. Although such an examination precludes the abandoned client's successor attorney from gaining such information, it would still require the disqualifying party to reveal it to the judge. See id. 213 (Castle, J., concurring in part and dissenting in part) (quoting T.C. Theatre Corp. v. Warner Bros. Pictures, Inc., 113 F. Supp. at 269). Moreover, there are practical difficulties militating against this solution. See text following note 120 infra.

One commentator has suggested that a special master be appointed to inspect the work product. Access to Work Product, supra note 30 , at 1072 n.83. This suggestion should be rejected because the master faces the same practical difficulties as the judge. See text following note 120 infra.

119 First Wis. Mortgage Trust v. First Wis. Corp., 584 F.2d 201, 218 (7th Cir. 1978) (en banc) (Castle, J., concurring in part and dissenting in part).

$120 \mathrm{Id}$. 212-13. Familiarity means a thorough understanding of the operations of the parties. Indeed, documents embodying confidences or secrets may at first glance seem innocuous to successor counsel as well as to the trial judge. In preparing the case, however, the successor is likely to spend substantial time familiarizing himself with all its aspects and studying the work product. Moreover, he is in a better position to comprehend the relationship between the parties; hence, he is more capable than the judge of discerning secrets or confidences contained in the written materials. Id. 218.

121 Id. 212; Consolidated Theatres, Inc. v. Warner Bros. Circuit Management Corp., 216 F.2d 920, 926 (2d Cir. 1954). 
preservation of the disqualifying party's secrets or confidences counsel against adoption of the "specific confidential information" approach to the problem.

The likelihood that confidences or secrets appear in the work product of the disqualified attorney must be analyzed to reconcile competing interests. These include the abandoned client's interest in mitigating the effects of the disqualification, the adverse party's interest in preserving his information, and the judiciary's interest in avoiding undue burdens upon the court's valuable time. Thus, a presumption like that invoked to decide the disqualification issue fails because it would not serve the abandoned client's interests. At the same time, a requirement of "actual confidences" undermines the interests of the disqualifying party and judiciary. To harmonize the three competing interests, the courts should examine certain variables to draw inferences about whether the disqualified attorney transmitted confidences to the work product. This approach is consistent with the interests of the abandoned client because it recognizes that different considerations govern the issues of work product and disqualification. Moreover, it avoids the "specific confidential information" requirement which is inimical to the disqualifying party and judiciary. In implementing this approach, the court should use information about the nature of the work product and its relation to the attorney who actually received confidences or secrets from the abandoned client.

\section{a. Nature of Work Product}

Certain products of legal work are more likely to contain confidences or secrets than others. ${ }^{122}$ Publicly filed documents such as briefs, pleadings, and motion papers, are unlikely to include such information because they are available for inspection by both the adverse party and the court. ${ }^{123}$ On the other hand, internal documents, such as office memoranda, letters to clients, and transcripts of strategy conferences, are most likely to contain confidences or secrets. ${ }^{124}$ These materials, which embrace the attorney's tactical ap-

122 See First Wis. Mortgage Trust v. First Wis. Corp., 584 F.2d 201, 216 \& n.8 (7th Cir. 1978) (en banc) (Castle, J., concurring in part and dissenting in part).

123 Id. The disqualifying party is unlikely to contest the turnover of materials that are part of the public record.

124 See VAND. L. Rev., supra note 30 , at 830, 832-33.

Although internal documents are more likely to contain confidences or secrets, some are much more likely to do so than others. The court must evaluate the likelihood that the work product contains secrets or confidences by focusing on the probable content of the document, not its "type." 
proach to the litigation and are, thus, protected from inspection by any adverse party, ${ }^{125}$ may contain information which might be used against the disqualifying party.

Other forms of work product, such as factual or descriptive materials, cannot easily be viewed as likely or unlikely to contain confidences. ${ }^{126}$ For instance, in an action on a contract for the sale of goods, a description of the inspection by the buyer on receipt of the goods would rarely contain the seller's secrets. On the other hand, an explanation of the performance promised by the seller is more likely to include confidences or secrets about the seller's operations procured by the attorney during his prior representation of the seller. ${ }^{127}$ The court, therefore, must deal with these types of work products on an ad hoc basis.

\section{b. Attorney Involvement}

If a law firm rather than an individual attorney is disqualified, ${ }^{128}$ it is probable that several attorneys produced the requested work product. In addition, the individuals who prepared the written materials in the present case may not have taken part in the prior representation of the disqualifying party. ${ }^{120}$ Hence, as the

125 Because of the likelihood that these dociments contain the "Iegal mind work" of an attorney, they are protected from discovery by the "work product privilege." FED. R. Crv. P. 26(b)(3) states that "[T]he court shall protect against disclosure of the mental impressions, conclusions, opinions, or legal theories of an attorney." See also note 19 supra.

126 As with internal documents, the court should focus here on the probable content of the written materials. See note 124 supra.

127 Without examining the documents, the court could learn the types of documents requested and their general content by employing the same method used to decide privilege claims. The disqualified attorney could prepare an inventory of the documents, accompanied by affidavits containing a general description of their contents. See Appellee's Petition for Rehearing and Modification of the Mandate at 7, First Wis. Mortgage Trust v. First Wis. Corp., 584 F.2d 201 (7th Cir. 1978) (en banc). Of course, if the documents sought number in the hundreds or thousands, such an inventory requires much work by an attorney and concomitant expense to the abandoned client. The inventory might simply list the number of documents of a particular class and their general content. For example, one entry might be: "Transcripts of five meetings between attorney and abandoned client, in which the circumstances leading up to the execution of the contract were discussed."

128 DR 5-105(D) states: "If a lawyer is required to decline employment or to withdraw from employment under a Disciplinary Rule, no partner, or associate, or any other lawyer affliated with him or his firm, may accept or continue such employment."

129 The courts have recognized that the degree of involvement of particular attorneys in conflicting representations should be considered in determining whether these individuals should be presumed to have obtained confidences or secrets. See, e.g., Westinghouse Elec. Corp. v. Gulf Oil Corp., 588 F.2d 221, 223 n.1 (7th Cir. 1978) (quoting Silver Chrysler Plymouth, Inc. v. Chrysler Motors Corp., 518 F.2d 751, 756-57 (2d Cir. 1975)); Government of India v. Cook Indus., Inc., 569 F.2d 737, 740 (2d Cir. 1978). 
overlap decreases between the individuals who presumably received secrets and confidences and those who prepared the work product, the possibility lessens that the written work embodies the disqualifying party's confidences. ${ }^{130}$

Thus, by examining the relationship between the two representations, the court may assess the relevance of the secrets and confidences that were presumably passed from the disqualifying party to the attorney or members of the firm. The court must then consider the nature of the work product and the degree of attorney overlap to determine the magnitude of the possibility that the written materials contain such information. Having determined the likelihood that the disqualifying party will be prejudiced if the work product is turned over, the court must then turn its attention to the harm which may result if the work product motion is denied.

\section{B. Harmful Effects Emanating From Denial of Work Product Motion}

Denying the work product motion may produce two types of harm. First, the delay and expense of duplicating the work product may harm not only the abandoned client but also the disqualifying party and the judicial system. Second, denial may prevent substitute counsel from thoroughly familiarizing himself with the case, depriving the abandoned client of effective assistance of counsel. While the first type of harm depends primarily on the volume of

For this reason, some courts have held that the presumption of receipt of confidential information, see note 43 supra, is rebuttable where an attorney is alleged to have received the confidence from others in his firm. See, e.g., Silver Chrysler Plymouth, Inc. v. Chrysler Motors Corp., 518 F.2d at 754 (citing cases); Canadian Gulf Lines, Inc. v. Triton Int'l Carriers, Ltd., 434 F. Supp. 691, 694 (D. Conn. 1976) (evidence rebutted presumption). See also Fred Weber, Inc. v. Shell Oil Co., 432 F. Supp. 694, 697 (E.D. Mo.), affd, 566 F.2d 602 (8th Cir. 1977), cert. denied, 436 U.S. 905 (1978) (refused to draw inference of confidential information).

The relationship of particular lawyers to the disqualifying party's confidences should also be considered when the court determines whether the work product is likely to contain confidences or secrets.

The court should bear in mind, however, that even if attorneys who had access to client confidences did not write the work product, they may have assisted those who did. First Wis. Mortgage Trust v. First Wis. Corp., 584 F.2d 201, 218 n.10 (7th Cir. 1978) (en banc) (Castle, J., concurring in part and dissenting in part).

130 To ascertain the degree of overlap, the court might request affidavits from the firm stating the names of attorneys who had contact with the disqualifying party during the firm's representation of it, as well as the extent of that contact. The court might also require that the affidavits accompanying the inventory of documents, see note 127 supra, include the names of attorneys who prepared the written material. By comparing the names of those attorneys who are presumed to have obtained secrets and confidences from the disqualifying party with the names of those who prepared the work product for the abandoned client, the court can assess the degree of overlap among those participating in the two representations. 
work which subsequent counsel must duplicate, the latter one depends on the nature and complexities of the litigation.

\section{Duplication of Work Product}

If the work product request is denied, substitute counsel for the abandoned client must duplicate some of the written work already done by disqualified counsel. This duplication may involve substantial expense and delay. Indeed, the financial burden alone may be so staggering that the abandoned client is effectively barred from further access to the courts. ${ }^{\mathbf{1 3 1}}$ Delay also may effectively bar either party from further adjudication or give one party an undue advantage. ${ }^{132}$ For example, such delay may be used by one party to induce his adversary to settle or withdraw his claim. ${ }^{133}$ Delay affects the judge as well. ${ }^{134}$

131 In First Wis. Mortgage Trust v. First Wis. Corp., for example, the work product required more than a year and 15 lawyers to produce. 584 F.2d 201, 204 (7th Cir. 1978). Had the work product request been denied, the attorneys' fees for duplication would have been enormous. Cf. Westinghouse Elec. Corp. v. KerrMcGee Corp., 580 F.2d 1311 (7th Cir.), cert. denied, 99 S. Ct. 353 (1978) (disqualifying firm had used 8 to 14 attorneys for over two years and collected $\$ 2,500,000$ in fees). After this disqualification decision, successor counsel considered requesting the disqualified attorneys' work product. Getting Kirkland Ellis' Westinghouse File, Nat'l L.J., Nov. 20, 1978, at 3, col. 1. See also Lasker, supra note 92 , at 250 (high cost of litigation bars most Americans from courts).

Although successor counsel, regardless of the outcome of the work product motion, will inevitably prepare many new materials, there are many documents produced by disqualified counsel which successor counsel could use without the need for duplication. In First Wisconsin, for example, the contested work product consisted of files on real estate transactions. These are of the type that would not have to be duplicated by successor counsel if the work product motion were granted.

Where the amount of work product in question is large, the burden of expense and delay on the abandoned client, of course, is correspondingly great. Still, there is a possibility that duplication of work product will not lead to added expense if the abandoned client withholds payment or seeks reimbursement from disqualified counsel. For an example of a lawsuit filed by an abandoned client seeking a refund of fees paid to a disqualified attorney, see Conflicts: When Big Isn't Better, Nat'l L.J., May 7, 1979, at 1 , col. 4.

132 "[J]ustice delayed is justice denied-at least in part. If the case is improperly brought, the emotional and financial burden should be lifted from the defendant as soon as possible ..... If the claim is a good one then excessive delay adds insult to injury for the plaintiff." Lasker, supra note 92 , at 250 .

133 In the context of the disqualification motion, courts have begun to recognize that delay may be used by the disqualifying party to harass his opponent. E.g., Board of Educ. v. Nyquist, 590 F.2d 1241, 1246 (2d Cir. 1979). Hence, some courts refuse to allow interlocutory appeal from orders denying disqualification. See, e.g., Melamed v. ITT Continental Baking Co., 592 F.2d 290, 295-96 (6th Cir. 1979) (prospective ruling); Community Broadcasting of Boston, Inc. v. FCC, 546 F.2d 1022, 1026-28 (D.C. Cir. 1976). See generally Comment, The Appealability of Orders Denying Motions For Disqualification of Counsel in the Federal Courts, 45 U. CrI. L. Rev. 450 (1978).

134 "The costs ... are not borne by the litigants alone. They are invariably felt by the judges themselves who sense keenly the lack of time to reflect, and the perils of hasty decision ... " Lasker, supra note 92 , at 250. 
Both the cost and delay of duplication depend on the volume of the requested work product. Of course, the court must consider more than the sheer number of documents. It must be wary of the roles played by the disqualifying party and the bench in the proliferation of the work product of the disqualified attorney. The amount of written work prepared by the disqualified attorney in some sense depends on the timing of the disqualification motion and order. The later the motion to disqualify is made, the longer the disqualified attorney has remained on the case. By raising the matter of disqualification earlier, the disqualifying party could have expedited the resolution of the issue: the disqualification would have occurred sooner, and the volume of written work produced by the attorney would have been reduced. The later the motion to disqualify is made, the greater the likelihood that the motion was timed to harass the abandoned client. ${ }^{135}$ Thus, the disqualifying party is responsible to some extent for the volume of work product prepared by counsel before disqualification. The court must consider this when deciding whether to reject the work product motion.

Similarly, the court must consider the amount of time elapsed between the making of the motion to disqualify and the ruling on the motion. ${ }^{136}$ When one party moves to disqualify, the abandoned client is placed in a difficult position. If he permits his attorney to continue working on the case, he risks wasting that work: the attorney may be disqualified and the work product unavailable to subsequent counsel. Should he pursue this reasonable course of action, ${ }^{137}$ the amount of work done by the attorney becomes a func-

135 On the effect of delaying the motion to disqualify, see Central Milk Producers Coop. v. Sentry Food Stores, Inc., 573 F.2d 988, 992 (8th Cir. 1978); Westinghouse Elec. Corp. v. Rio Algom Ltd., 448 F. Supp. 1284, 1306 (N.D. Ill.), rev'd in part sub nom. Westinghouse Elec. Corp. v. Kerr-McGee Corp., 580 F.2d 1311 (7th Cir.), cert. denied, 99 S. Ct. 353 (1978). The use of the motion to disqualify for strategic purposes is discussed in Van Graafeiland, Lawyer's Conflict of Interest-A Judge's View, N.Y.L.J., July 20, 1977, at 1, col. 2. See also Melamed v. ITT Continental Baking Co., 592 F.2d 290, 295-96 (6th Cir. 1979); Board of Educ. v. Nyquist, 590 F.2d 1241, 1246 (2d Cir. 1979); Community Broadcasting of Boston, Inc. v. FCC, 546 F.2d 1022, 1027 (D.C. Cir. 1976); Ross v. Great Atl. \& Pac. Tea Co., 447 F. Supp. 406, 410 (S.D.N.Y. 1978).

Attorney Work Product, supra note 30 , at 552-53 suggests that the disqualifying party may deliberately seek to increase the size of the work product while the disqualification motion is pending.

136 See First Wis. Mortgage Trust v. First Wis. Corp., 584 F.2d 201, 205 (7th Cir. 1978) (en banc).

137 Alternative courses of action are undesirable; thus, this course of action is likely to be followed. The client may decide that counsel should do no further work until the motion is ruled on, but the client then forfeits valuable time during which his case could be developed. See Petition for Rehearing with Suggestion that the Rehearing Be En Banc, at 6, First Wis. Mortgage Trust v. First Wis. 
tion of the timing of the court's decision on the motion. A dilatory ruling on the disqualification motion contributes to the production of work product by the disqualified attorney, augmenting the amount of work which will be duplicated if the work product motion is denied. ${ }^{138}$

The amount of work product which will have to be duplicated by subsequent counsel, then, is determined by the volume of written materials prepared for the case. When assessing the harm inflicted on the abandoned client, however, the court must also consider the extent to which the disqualifying party and court contributed to the proliferation of the work product. The greater the contribution, the more compelling the reason to permit the work product to be turned over.

\section{Danger of Inadequate Representation}

The abandoned client faces a danger even more pernicious than the burdens of duplication of the work product: denial of the work product motion may cause inadequate legal representation. This problem can take two forms. First, there may be portions of the work product that substitute counsel is simply unable to recreate. Second, without the work product, substitute counsel may be significantly less prepared than opposing counsel.

Substitute counsel's ability to duplicate the work product depends primarily on the timing of the disqualification. The earlier that substitute counsel takes over the litigation, the more likely he will be able to investigate and prepare as though he had been involved from the outset. Moreover, at an early stage, the work product of disqualified counsel will likely be less extensive and correspondingly less helpful to the substitute. ${ }^{139}$

Corp., 571 F.2d 390 (7th Cir. 1978). Alternatively, he may dismiss counsel. By adopting this approach, however, the client not only loses the services of the attorney most familiar with the case but permits a possibly meritless disqualification motion to disrupt and debilitate his representation. Id.

138 In First Wisconsin, the trial court did not rule on the motion to disqualify for 15 months. 584 F.2d at 205. (The disqualification decision is reported at 422 F. Supp. 493 (E.D. Wis. 1976)).

See Attorney Work Product, supra note 30, at 552-53; text accompanying notes 157-59 infra.

139 In some cases, however, the disqualified attorney may have spent much time working on the case before the litigation commenced. Thus, even if the disqualification were ordered early in the litigation, there might be a substantial body of work product of use to successor counsel. In such a case, the considerations governing disqualifications ordered late in the litigation are relevant. 
If, however, disqualification is ordered at a later stage of the litigation, ${ }^{140}$ it becomes more difficult to reconstruct the information necessary for representation. For example, witnesses may be unavailable, or real evidence may have disappeared or been altered. ${ }^{141}$ If substitute counsel enters the case so late that he is unable to reconstruct material factual information, the abandoned party may be unable to proceed with his case. ${ }^{142}$

At the same time, even if no key piece of information is missing, the work product may be important to substitute counsel's understanding of the case. This depends, in the first instance, on the complexity of the litigation. The more voluminous and intricate the fact patterns and legal issues, the more difficult they are for successor counsel to comprehend fully.

The successor's ability to handle the issues of the case is also closely related to the timing of his assumption of the case. The later he takes over, the more he must rely on facts and litigation strategy developed by the disqualified attorney. ${ }^{143}$ Even if he could develop the case without resort to the work product, he would likely have insufficient time to do so: with the litigation having already progressed substantially, opposing counsel would be eager to proceed. Having participated in the litigation throughout, he will have already developed his case; thus, he will exert pressure on

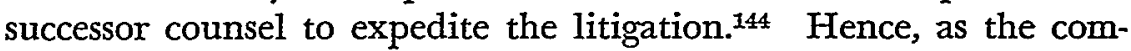

140 E.g., Central Milk Producers Coop. v. Sentry Food Stores, Inc., 573 F.2d 988 (8th Cir. 1978) (motion to disqualify made five years after firm had begun work on lawsuit and two years after attorney in question, a former FTC lawyer, had joined firm).

141 E.g., Canadian Gulf Lines, Inc. v. Triton Int'l Carriers, Ltd., 434 F. Supp. 691, 696 (D. Conn. 1976) ("The prejudice involved could be more than just a surmountable hardship, since the affidavits indicate that the information collected by [disqualified counsel] . . . may be essentially unavailable at this time or in the future.").

142 E.g., id. 695 (denying work product would probably prevent successor from making successful claim in main action).

Some courts have refused to disqualify an attorney where they fear that substitution of counsel would significantly harm the party's case. E.g., Central Milk Producers Coop. v. Sentry Food Stores, Inc., 573 F.2d 988, 992 (8th Cir. 1978); Ross v. Great Atl. \& Pac. Tea Co., 447 F. Supp. 406, 409-10 (S.D.N.Y. 1978). Cf. DR 5-101(B)(4) (lawyer, ordinarily precluded from accepting employment in case in which he will testify, may undertake employment "if refusal would work a substantial hardship on the client because of the distinctive value of the lawyear [sic] or his firm as counsel in the particular case").

Even if the formal discovery process has not been completed, so that successor attorney may participate in it, he may not have a sufficient understanding of his client's case to know how to approach the inquiry.

143 See notes 140-41 supra \& accompanying text.

144 Of course, if opposing counsel believes that delay is advantageous, he would refrain from urging his counterpart to hasten the development of his case. The 
plexity of the issues increases and the course of the litigation progresses, the reason for the court to make the work product available becomes more compelling.

In gauging the effects on the abandoned client of a denial of the work product request, then, the court must assess the likelihood that he will be inadequately represented as well as the economic burden and delay in litigation which will beset him. Against these considerations, the court must balance the likelihood that confidences and secrets passed from the disqualifying party to the disqualified attorney will be used to that party's detriment should the work product motion be granted. From this balancing, the court must decide whether to authorize a turnover of the work product to the abandoned client for use by his subsequent attorney.

\section{The Balancing Analysis and First Wisconsin Mortgage Trust v. First Wisconsin Corp.}

In First Wisconsin Mortgage Trust v. First Wisconsin Corp., the court disqualified defendants' law firm due to its prior simultaneous representation of all parties to the litigation. ${ }^{145}$ Although the court did not expressly rely on any of the canons as the basis for disqualification, its use of the substantial relationship test implies that it found the strictures of Canon 4 to have been contravened. ${ }^{146}$ Accordingly, the subsequent request by the defendants, for authorization to obtain certain work product produced by disqualified counsel for use in the litigation, ${ }^{147}$ is subject to the balancing analysis.

\section{A. Likelihood That Confidences or Secrets Will Be Used Against Adverse Party}

The relationship between the subject matter of disqualified counsel's prior representation of the disqualifying party and the subsequent lawsuit assures the relevance to the litigation of con-

effects on the abandoned client, however, might still be detrimental. See note 132 supra \& accompanying text.

145422 F. Supp. 493 (E.D. Wis. 1976) (disqualification decision). For a brief discussion of the facts and procedural history of the case, see note 24 supra \& text accompanying notes 19-24 supra.

146 Id. 498; 74 F.R.D. 625, 626 (E.D. Wis. 1977), aff'd, 571 F.2d 390 (7th Cir.), rev'd, 584 F.2d 201 (7th Cir. 1978) (en banc) (work product decision).

147 Most of the work product requested was prepared prior to the filing of the lawsuit. However, whether the work product was produced prior to or during the litigation was of no consequence because the law firm that prepared it was held to have been disqualified $a b$ initio. 74 F.R.D. at 628 . 
fidences and secrets presumably passed to counsel from the disqualifying party: the primary suit in First Wisconsin concerned the obligations owed by the defendants to the plaintiff as set forth in documents drafted by disqualified counsel during its prior simultaneous representation ${ }^{148}$ of both parties as general counsel. Thus, the very heart of the prior representation was the focus of the subsequent litigation.

Although it is certain that plaintiff's confidences and secrets were relevant to the litigation, it is relatively unlikely that such information was present in the work product. The written work at issue consisted "essentially of summaries of loan files relating to more than 300 complex [real estate] transactions." 149 Characterized by the appellate court as "the result of routine lawyer work of a type any competent lawyer . . . could accomplish," 150 the summaries were purely factual. Moreover, the files which were the subject of the summaries were available to both parties. ${ }^{151}$ The nature of the work product, then, suggests that it did not contain the disqualifying party's confidences or secrets. ${ }^{\mathbf{1 5 2}}$

Further, although not expressly stated in the facts of the case, the work product was apparently prepared by attorneys who did not have access to the confidences and secrets of the disqualifying party. The work product was produced by fifteen members of the disqualified law firm, who spent more than a year analyzing the files and writing the summaries. ${ }^{153}$ It is probable that the attorneys who prepared the work product were young associates. ${ }^{154}$ Whether these attorneys also took part in the prior representation is not clear; in any event, they likely had insufficient contact with the disqualifying party to receive confidences or secrets.

\section{B. Adverse Effects On Abandoned Client}

If the court had denied the motion, successor counsel would have had to duplicate substantial work. The documents at issue,

148422 F. Supp. 493, 494-96, 498 (E.D. Wis. 1976) (disqualification decision). 149584 F.2d 201, 204 (7th Cir. 1978) (en banc) (work product decision) (quoting abandoned client).

$150 \mathrm{Id}$.

151 Id. 210.

152 The opinion of the court sitting en banc includes an assertion that the work product does not involve confidential information. Id. 204. In his opinion concurring in part and dissenting in part, Judge Castle takes issue with this bald declaration. Id. 211 \& n.I. He concludes that it is possible that confidences were contained in the work product and that this possibility alone is sufficient to deny the work product request. Id. 217-19. His opinion is criticized at note 109 supra. 153584 F.2d 201, 204 (majority opinion).

154 Id. 218 n.10 (Castle, J., concurring in part and dissenting in part). 
representing more than a year of work by fifteen attorneys, ${ }^{155}$ constituted a significant portion of the work done by the entire firm during that period. ${ }^{156}$ Thus, the expense of duplication, with the delay in litigation which inevitably would result, is substantial.

Moreover, while plaintiff declared its intention to move to disqualify counsel three months after the litigation commenced, it did not actually file its motion until nearly five months after the action was commenced. ${ }^{157}$ Further, the court's ruling on the disqualification motion was not entered for an additional fifteen months. ${ }^{158}$ Although the work product at issue appears to have been completed months before the disqualification order was granted, the delays in the filing of the motion and the ruling of the court lengthened the period during which the firm remained on the case. These delays undoubtedly contributed to the amount of work product produced by disqualified counsel. . $^{159}$

At the same time, a denial of the work product request might have affected the adequacy of successor counsel's representation. The loan files which were summarized in the work product contained complex and highly technical documents. ${ }^{160}$ Given adequate time, successor counsel could have duplicated the summaries, but such time might have been lacking. Two years had passed since the plaintiff initiated the litigation, and successor counsel would have had to request a delay of at least a year ${ }^{161}$ in order to duplicate the work product. Opposing counsel, having spent nearly two years working on the case, would have been unlikely to agree to a long

155 Id. 204 (majority opinion).

${ }^{156}$ As of July 1977, the disqualified firm, Foley \& Lardner, had 138 lawyers. Cantor, Law Firms Are Getting Bigger . . . and More Complex, 64 A.B.A.J. 215, 218 (1978).

157 Brief for Appellants, supra note 17, at 10 .

158 First Wis. Mortgage Trust v. First Wis. Corp., 584 F.2d 201, 205 (7th Cir. 1978) (en banc).

159 "The work product was voluminous at the time Plaintiff filed its motion and had grown further by the end of the extended interval between the filing of the motion and the Decision and Order granting it." Brief for Appellants, supra note 17, at 13 (footnote omitted).

160 Id. 15.

161 This assumes that the substitute firm would be able to assign 15 attorneys to duplicate the summaries. The disqualified firm employed 15 lawyers for one year to create them. See 584 F.2d at 204. Of course, if the substitute firm were able to assign more than 15 attorneys to the task of preparing the summaries, the documents might be completed in a shorter period. 
delay. ${ }^{162}$ Thus, the substitute firm would have been placed in a situation in which it would likely have been unable to prepare fully the needed summaries. Unless the work product was available, the substitute firm may have been unable to provide adequate representation.

\section{Balancing}

The result reached by the Seventh Circuit in its en banc rehearing of First Wisconsin was proper. The magnitude and complexity of the work product and the timing of the disqualification order would have translated into great expense and delay, and probable prejudice to the defendants, had the work product request been denied. These effects outweigh the possibility that confidences and secrets would have been used to the plaintiff's detriment if the motion had been granted. The nature of the work product, and the identity of the attorneys who probably produced it, minimize the likelihood that the plaintiff would have been disadvantaged.

\section{ConcLusion}

The work product of a disqualified attorney should be made available to substitute counsel except when withholding it is required to enforce the ethical purpose of disqualification. ${ }^{163}$ The only ground for disqualification which justifies withholding the work product is the possibility that secrets or confidences reposed in an attorney will be used to his client's detriment.

The mere possibility of such use, however, does not justify a denial of the work product motion. The harm to the client whose attorney was disqualified is potentially too serious to be permitted without compensating benefits. Thus, courts should employ a balancing analysis to determine the availability of the work product: they should weigh the possibility that secrets or confidences will be used to the disqualifying party's detriment if the work product is made available, against the harm to the abandoned client if the work product is withheld.

162 The court might have ordered the delay. In that case, however, opposing counsel could have sought to use the delay to his advantage. See note 109 supra.

163 It should be noted that the work product issue as discussed in this Comment raises substantial questions of professional ethics, fundamental fairness, and the spiraling cost of litigation. The scope of this Comment, however, has not permitted extensive focus on these issues. 
Courts have come to recognize that when an attorney is disqualified, his abandoned client may be severely disadvantaged. ${ }^{\mathbf{1 6 4}}$ In proposing a balancing analysis, this Comment seeks to insure that, when the issue shifts from the attorney's conduct to the attorney's work product, courts pay adequate attention to the interests of the abandoned client.

164 See, e.g., Government of India v. Cook Indus., Inc., 569 F.2d 737, 739 (2d Cir. 1978); Norman Norell, Inc. v. Federated Dep't Stores, Inc., 450 F. Supp. 127, 130-31 (S.D.N.Y. 1978); Canadian Gulf Lines, Inc. v. Triton Int'l Carriers, Ltd., 434 F. Supp. 691, 695-97 (D. Conn. 1976). 